\title{
Genesis of the Bible documentary: the development of religious broadcasting in the UK
}

\author{
Richard Wallis
}

\section{Introduction}

Television genres and sub-genres are rarely stable over time. The Bible documentary is a form of factual programme making that emerged recognizably during the 1970s, reflecting broader stylistic trends in television. Today more than ever, in a climate in which the stakes are high for the winning and retention of audiences, television commissioning editors are caught between a cultural aversion to risk-taking, and an ambition to claim the next big 'genre-busting' hit. The consequence of these contradictory pressures is that programme genres are not so much invented as developed through a process of cultivated adaptation and hybridity: a tendency towards small iterative changes. To a significant extent, the template for the modern 'authored' documentary remains the seminal Civilisation (BBC, 1969): art historian, Kenneth Clark's personal view of the philosophy, art, and architecture of the Western world. The remarkable impact of this thirteen-part series is attributable, in part, to the erudition and urbane authority of its on-screen presenter (Clark was knighted for his achievements), and in part to its visual richness (being one of the first such series to be filmed in colour) establishing the lavish travelogue style. It was this approach that was repeated by Civilisation's producer, Peter Montagnon, in his subsequent thirteen-part series The Long Search (BBC, 1977), written by the scholar Ninian Smart, which examined the world's major religions.

There are other reasons, however, why the documentary was embraced as a vehicle for religious programmes during the 1970s, and its particular history should be understood in 
Genesis of the Bible documentary: the development of religious broadcasting in the UK. Chapter for Adams, E. \& Bond, H. (Eds), 2019 The Bible on Television (London: Bloomsbury). This document is the author's submitted version. There may be differences between this version and the published version. You are advised to consult the publisher's version if you wish to cite from it.

the context of the evolution of religious broadcasting in the UK more generally. This chapter aims to provide this broader frame. The way in which religious broadcasting was established, and the way it subsequently evolved over its first five decades, is central to understanding how and why the Bible documentary emerged as it did, when it did. As will be seen, the transition from a radio-dominated, to a television-dominated, broadcasting era was marked by a number of important cultural shifts that had significant impact on religious broadcasting practice. It is against this background that the developments that follow (and are discussed by others in this volume) may be understood. In particular focus here are: the way in which Bible-related themes came to be treated within the documentary genre; the controversies and tensions that have arisen, especially between broadcasters and the churches; and the changing role that advisors and 'experts' have played throughout.

\section{Religion on 'the wireless'}

Religion has been part of broadcasting output in the UK since Christmas Eve 1922, when the Rector of Whitechapel delivered the first 'wireless' sermon. In his address, he wondered at the extraordinary technological development that had enabled him, in one moment, to speak to more people than the Apostle Paul had done in his entire lifetime. Such technological developments had certainly been profound, but it would be a mistake to assume that it had been technology that had determined the way in which public service broadcasting developed, or that there was anything inevitable about the way in which religious programmes evolved with reference to it. The BBC Charter of 1927 - like the Television Act that was to follow twenty-seven years later - carried no mandatory requirement that religious content should to be produced. Yet religious programmes have played an important part in the story of UK broadcasting since its inception. The way in which this occurred, the forms that programmes took, and the role that advisors and experts came to play, is largely due to the distinctive and formative role played by the BBC's first Director-General, John Reith. 
Genesis of the Bible documentary: the development of religious broadcasting in the UK. Chapter for Adams, E. \& Bond, H. (Eds), 2019 The Bible on Television (London: Bloomsbury). This document is the author's submitted version. There may be differences between this version and the published version. You are advised to consult the publisher's version if you wish to cite from it.

Reith was the son of a Presbyterian minister and viewed his position in terms of a 'calling'. He was determined that the BBC should actively promote religion, and that this should be of the right kind. He held strong personal Christian convictions while being generally opposed to narrow dogmatism. Reith wanted the BBC to represent a practical, non-denominational faith, broadly representative of what he thought of as the main stream of historic Christianity.

As the Sunday evening address became a regular feature of BBC output, Reith established a 'Sunday Committee' to provide him with expertise and advice. This small hand picked group of clerics was intended to be broadly representative of the Christian churches, but crucially, chosen by Reith and not their institutional constituencies. By July 1926 the group had become known as the Religious Advisory Committee, and later, as regional advisory committees were set up, it became the Central Religious Advisory Committee (CRAC). CRAC was to be the model for advisory committees on a number of subject areas during the early years of the BBC, and extended its influence still further with the establishment of ITV. Its central role in the evolution of religious broadcasting, the relationship between it and the religious institutions that it ostensibly 'represented', and its defence (and sometimes criticism) of broadcasting practices, are an essential part of this story.

CRAC's early role was primarily to offer advice to the BBC on Sunday speakers. It also provided a line of resistance to sustained criticism of the BBC's approach to religion, including from many within the churches, some of whom believed that the medium and the message were simply incompatible. In 1923, for example, the Chapter of Westminster rejected the request to broadcast the marriage service of the Duke of York (soon to be King

${ }^{1}$ Andrew Boyle discusses in some detail Reith's religious convictions in his biography Only The Wind Will Listen: Reith of the BBC. (1972) London: Hutchinson and Co. Ltd. 
Genesis of the Bible documentary: the development of religious broadcasting in the UK. Chapter for Adams, E. \& Bond, H. (Eds), 2019 The Bible on Television (London: Bloomsbury). This document is the author's submitted version. There may be differences between this version and the published version. You are advised to consult the publisher's version if you wish to cite from it.

George VI) on the grounds that men in public houses might be listening with their hats on ${ }^{2}$. Three years later, the magazine Life of Faith, published a series of letters debating the question of whether or not the very medium was the work of the devil. One contributor demanded: 'Are we not told to avoid even the appearance of evil? "Come out from among them and be ye separate". "Touch not the unclean thing". Are not the world's pleasures, the wireless, cinema, etc. unclean today?'3 At a purely pragmatic level, there were widespread concerns that the broadcasting of church services might result in a fall in church attendance. At the same time, organizations like the British Humanist Association, the Rationalists and Fabian Society objected to the primacy of place being given to the Christian religion, whilst groups like the Christian Scientists and the Seventh Day Adventists were angered at having been excluded by what the BBC had decided constituted 'mainstream'.

Against this criticism, Reith enlisted allies from those who shared his own vision for 'BBC religion': a version of Christianity best illustrated by his recruitment of Dick Sheppard, vicar of St. Martin-in-the-Fields. Sheppard was initially drafted in to join the Sunday Committee, but subsequently became a major contributor to the BBC's output, with broadcasts from St Martin's becoming a staple part of the BBC's output (continuing to the present). Sheppard's 'diffused rather than sectional Christianity'4 was what Reith identified as the middle ground of Christian consensus, and justified in terms of the BBC's public service duties:

\footnotetext{
In a national service to which nothing that pertains to the life of men is foreign, it was natural that from the beginning religion should find its place in British Broadcasting. It could not be otherwise. Even if the programmes aimed only at providing education and recreation, religion could not be denied a place; but when those who were responsible for Broadcasting set before themselves the object of raising the
}

\footnotetext{
${ }^{2}$ K.M. Wolfe (1984) Churches and the BBC 1922-1956, London: SPCK, p.79.

${ }^{3}$ Life of Faith, 11 August 1926.

${ }^{4}$ K.M. Wolfe (1984), p.8.
} 
Genesis of the Bible documentary: the development of religious broadcasting in the UK. Chapter for Adams, E. \& Bond, H. (Eds), 2019 The Bible on Television (London: Bloomsbury). This document is the author's submitted version. There may be differences between this version and the published version. You are advised to consult the publisher's version if you wish to cite from it.

national standard of values and of a constructive idealism, it was obvious that the religious service should be one of the regular programme features. ${ }^{5}$

What was obvious to Reith was not obvious to everyone, yet Reith pursued his vision with energy. Reith wanted more than just church services and epilogues. The first religious 'talks' series was God and the World Through Christian Eyes (BBC, 1933). Across two 12part series', eminent academics and theologians addressed themselves to a range of subjects broadly grouped around the themes of 'God', 'Christ', 'Man and His World', and 'Christianity'. In the first series, J.Y. Simpson, Professor in Natural Science at New College Edinburgh, spoke on Science and the Idea of God; Maude Royden, the theologian and suffragist, spoke on God and the World of Art; and the New Testament scholar, C.H. Dodd, spoke on 'Christ Crucified'. Much effort was concentrated in trying to find the most engaging and convincing speakers to communicate Christian ideas. Being an ardent Sabbatarian, such programmes - and only such programmes - dominated Sunday broadcasting, although nothing was broadcast during the normal hours of church services. Early religious broadcasting on 'the wireless', therefore, consisted of a limited Sunday listening diet of mainly church services, sacred music, talks, and (sometimes more ambitious) religious educational content aimed at children.

\section{The War years and after}

Reith departed from the BBC in 1938. The War Years that followed constituted the period that most solidly established the Corporation's reputation as an institution of national and cultural importance. As well as being a reassuring source of information and entertainment, it also became an instrument of national unity as it developed more of a mass audience appeal. The changes that resulted from the BBC's role of keeping the nation cheerful were evidenced in all departments, including new opportunities for religious broadcasting. The

${ }^{5}$ B.B.C. Handbook, 1928, p.131. 
Genesis of the Bible documentary: the development of religious broadcasting in the UK. Chapter for Adams, E. \& Bond, H. (Eds), 2019 The Bible on Television (London: Bloomsbury). This document is the author's submitted version. There may be differences between this version and the published version. You are advised to consult the publisher's version if you wish to cite from it.

accessible combination of fireside chat, theology, and Christian apologetics, made the wartime talks of contributors like C S Lewis enormously popular ${ }^{6}$.

One of the most ambitious projects during this period was The Man Born to be King ${ }^{7}$. James Welch, Director of Religious Broadcasting, commissioned the popular crime writer, Dorothy L. Sayers to write a dramatization of the life of Christ for the Sunday Children's Hour. Sayers, who had also written works of theological scholarship ${ }^{8}$, agreed on the condition that the character of Jesus should be portrayed with the same degree of realism as other characters, and not 'lost in a kind. . . of Apollinarian mist'. The result provoked a good deal of controversy. Many objected to the very idea of a Bible dramatization. The Lord's Day Observance Society asked the BBC to 'refrain from staging on the wireless this revolting imitation of the voice of our Divine Saviour and Redeemer' ${ }^{10}$. The campaign prompted over two thousand letters of complaint prior to the broadcast, although the subsequent reception of the programmes was mostly favourable. The (eventually acknowledged) success of the series signified that religious broadcasting did not have to be limited to devotional talks and church services.

The BBC television service pioneered from 1936, but closed at the beginning of the war, was re-opened when hostilities ended. Initially television was treated as radio with pictures. The first televised religious programme was a service of consecration of a war memorial chapel at Biggin Hill, transmitted on 15 September 1946, but only an enthusiastic minority had the equipment to view it. It was not until the Coronation of 1953 that general public

\footnotetext{
${ }^{6}$ Lewis' talks were adapted and published in 1952 as Mere Christianity (New York: Macmillan).

${ }^{7}$ Dorothy L Sayers, The Man Born to Be King: A Play-Cycle on the Life of Christ, BBC, 1941-42.

${ }^{8}$ Dorothy L Sayers (1941) The Mind of the Maker (London: Methuen) was published the same year.

${ }^{9}$ Cited in K.M. Wolfe, (1984). p.219.

${ }^{10}$ Letter to the BBC: H H Martin of The Council of the Lords' Day Observance Society. 12 December 1941.
} 
Genesis of the Bible documentary: the development of religious broadcasting in the UK. Chapter for Adams, E. \& Bond, H. (Eds), 2019 The Bible on Television (London: Bloomsbury). This document is the author's submitted version. There may be differences between this version and the published version. You are advised to consult the publisher's version if you wish to cite from it.

interest in television was really awakened, although the thought of television cameras violating the 'rightful intimacy'11 of the ceremony was too much for some. Fears were expressed particularly about intrusion into the sacred environment east of the church screen. After some considerable negotiation and compromise, permission to televise was granted, and the effect of the broadcast on the general public was significant, as for the first time, a television audience exceeded that of a radio audience. The new age of television had dawned.

\section{The aims of religious broadcasting}

Throughout the war years, CRAC's definition of the aims of religious broadcasting remained true to Reith's original vision 'to make Britain a more Christian country' ${ }^{12}$. In a report prepared for CRAC in October 1948 'four distinguishable aspects of this aim' were set out:

1. To maintain standards of truth, justice and honesty in private and public life.

2. To explain what the Christian faith is, to remove misunderstanding of it and to demonstrate its relevance today.

3. To lead 'non-churchgoers' to see that any really 'Christian' commitment involves active membership of an actual church congregation and to give 'churchgoers' a wider vision of what church membership involves.

4. To provide opportunities for that challenge to personal faith in Jesus Christ as Saviour and Lord which is the heart of 'conversion'. ${ }^{13}$

Reith's original view that the Corporation's entire output should be based upon 'the stated

\footnotetext{
${ }^{11}$ K.M. Wolfe (1984), p.498.

12 Broadcasting and religion. BBC Handbook 1928. London: BBC, pp.131-133.

${ }^{13}$ Confidential paper prepared for CRAC in October 1948 by Frances House. BBC Archives.
} 
Genesis of the Bible documentary: the development of religious broadcasting in the UK. Chapter for Adams, E. \& Bond, H. (Eds), 2019 The Bible on Television (London: Bloomsbury). This document is the author's submitted version. There may be differences between this version and the published version. You are advised to consult the publisher's version if you wish to cite from it.

and official religion of the country ${ }^{\prime 14}$, positioned religious broadcasting as the Corporation's missionary arm. No programmes had been allowed to present attacks or undermine this position. Despite the ban on controversy having been lifted the year before, in 1948 the then Director-General, William Haley stated:

There are many demands of impartiality laid upon the Corporation but this is not one of them. We are citizens of a Christian country, and the BBC - an institution set up by the State - bases its policy upon a positive attitude towards Christian values. It seeks to safeguard those values and to foster acceptance of them. The whole preponderant weight of its programmes is directed to this end. ${ }^{15}$

Nevertheless, the world was changing. Ever since God and the World Through Christian Eyes, there had been pressure from both within the Corporation and elsewhere to allow a certain amount of dialogue between Christians and non-believers. In 1949 Lord Beveridge (the principal architect of the welfare state) was asked to undertake a broadcasting review, primarily to examine the BBC's position of monopoly. The Report's discussion of religious broadcasting is of particular interest in that it distinguishes between two responsibilities of the BBC: first, the 'highest duty' of the Corporation to make an 'impartial search for truth'; and second, those duties of an institution 'set up by the State in a Christian country': 'The two considerations are reconciled in practice by having both controversial broadcasting and religious broadcasting as distinct activities of the $\mathrm{BBC}^{\prime 16}$. This distinction of activities, the Report observed, took place through the functions of the Talks Department and the Religious Department respectively. The clear implication here is that the Religious Department has a duty to propagate the Christian faith, while the Talks Department has the 'higher' duty to seek after 'truth' impartially, although this should be done 'in close consultation' with the Religious Department. We see here, then, the advancement of a

\footnotetext{
${ }^{14}$ J.C.W. Reith (1924) Broadcast over Britain, London: Hodder and Stoughton, p.192.

15 William Haley (1948) Moral Values in Broadcasting. Address to the British Council of Churches.

${ }^{16}$ Report of the Broadcasting Committee 1949 (1951) [The Beveridge Report], Cmd. 8116. London: HMSO, p.63.
} 
Genesis of the Bible documentary: the development of religious broadcasting in the UK. Chapter for Adams, E. \& Bond, H. (Eds), 2019 The Bible on Television (London: Bloomsbury). This document is the author's submitted version. There may be differences between this version and the published version. You are advised to consult the publisher's version if you wish to cite from it.

gradual process in which a religious paradigm shifts from being the basis of general broadcasting policy, to becoming the basis of the broadcasting policy of the Religious Department alone. Beveridge's response to complaints of exclusion from non-religious groups like the Ethical Union, was to recommend that they be allotted time by the Talks Department. The Report also suggested that the Governors should consider a 'Hyde Park of the air' to allow other minorities to put over their views. A statement published in the Radio Times summarized the change as allowing broadcasting to 'move within the climate of public opinion'17. The profound importance of this distinction was not felt for some time. It was, however, a shift that was to have significant repercussions over the following years.

\section{Religious broadcasting in competition}

The decision to allow 'some element of competition' ${ }^{18}$ in television was made in 1952 . The $\mathrm{BBC}$ would maintain its monopoly of radio broadcasting only. $\mathrm{BBC}$ television was to be subject to commercial competition. Reith's now famous outburst in the House of Lords demonstrates the strength of feeling that there was on the subject:

A principle absolutely fundamental and cherished is scheduled to be scuttled... Somebody ...introduced Christianity and printing and the uses of electricity. And somebody introduced smallpox, bubonic plague and the Black Death. Somebody is minded now to introduce sponsored broadcasting into this country. ${ }^{19}$

Despite many objections, the Television Act of 1954 established an Independent Television Authority (ITA) to govern the newly emerging independent television companies, of which there were initially four: Associated-Rediffusion; Associated Television; Granada; and the Kemsley-Winnick Group.

\footnotetext{
${ }^{17}$ Radio Times, BBC. 15 March 1947.

${ }^{18}$ White Paper on Broadcasting Policy, 1952. Cmd. 5550. London: HMSO.

${ }^{19}$ Lord Reith's speech to the House of Lords. 22 May 1952, Hansard Col. 1297.
} 
Genesis of the Bible documentary: the development of religious broadcasting in the UK. Chapter for Adams, E. \& Bond, H. (Eds), 2019 The Bible on Television (London: Bloomsbury). This document is the author's submitted version. There may be differences between this version and the published version. You are advised to consult the publisher's version if you wish to cite from it.

The first religious programme on ITV was an Epilogue (Associated Rediffusion) broadcast on the first day of transmission, 22 September 1955. A broadcast service took place in November (ATV). The first religious discussion programme, About Religion (ATV) followed later, although religious broadcasting on both BBC television and ITV was initially fairly limited. This, however, changed significantly when ITV took the decision to begin broadcasting within the dead seventy minute break in transmission on a Sunday evening between $6.15 \mathrm{pm}$ and $7.25 \mathrm{pm}$ (assumed to be the normal hours of church worship). Restrictions on broadcasting hours imposed by the Postmaster-General had enforced this 'closed period'. Ironically, however, because religious broadcasting was exempt from the rules of broadcasting hours, it was this very time that was adopted for the broadcast of religious programmes. Eventually, by agreement between the BBC and the ITA, religious programmes were transmitted simultaneously within this period ('back-to-back'). The result was that religious television broadcasting suddenly increased dramatically to take full advantage of the additional time.

Church services continued to be broadcast on television in much the same way as had been done on radio (although the operation was far more costly). After some initial caution from the churches, they were eventually welcomed, and considered to be a way of 'opening-up' the rituals and practices of the churches to those who, for various reasons, would not go to church themselves. Audiences were presumed to be religiously sympathetic, if not actively committed (typically thought of as the would-be churchgoer who was sick or housebound). It was an approach that remained largely unchanged up to the 1990s (albeit with some occasional experimentation with studio-based alternatives, mainly by the BBC). ITV's longrunning Morning Worship (ITV) - the 'citadel' of its output ${ }^{20}$ - was transmitted live each Sunday from a different location, and contained no narrative comment or interruption. The

${ }^{20}$ As described in E. Croston (Ed.) (1983) IBA Yearbook: Television \& Radio. London: Independent Broadcasting Authority. 
Genesis of the Bible documentary: the development of religious broadcasting in the UK. Chapter for Adams, E. \& Bond, H. (Eds), 2019 The Bible on Television (London: Bloomsbury). This document is the author's submitted version. There may be differences between this version and the published version. You are advised to consult the publisher's version if you wish to cite from it.

presiding minister might welcome viewers as fellow participators in worship, and the service conducted as if it were an ordinary local church gathering.

The 1954 Television Act, like the BBC Charter, lays no mandatory requirement on independent television companies to produce religious programmes. The ITA were to ensure that programmes 'contain a suitable proportion of matter calculated to appeal to the tastes and outlook of persons served by the station' and, as far as possible, ensure that 'the programmes maintain a proper balance in subject matter and general standard of quality.' Beyond this the Act only required that when religious programmes were produced, they be made in consultation with a religious advisory panel 'representative of the main streams of religious thought' ${ }^{21}$. Not surprisingly, therefore, it was to the already established Central Religious Advisory Committee (CRAC) that the ITA turned.

By the time that CRAC became the advisory body for the ITA, its task had become considerably broader than simply advising the BBC on Sunday speakers. It now advised on the whole gamut of religious broadcasting on both BBC radio and television. It had also developed to include prominent clergy and lay people of all denominations that were in membership of the British Council of Churches and Roman Catholic Church. It was in this way that the problem of what constituted 'main streams of religious thought' was justified (although the group was later widened to include representation of the Jewish faith, and eventually other religious traditions). The BBC and ITA made appointments to CRAC jointly, 'in consultation with the churches' ${ }^{22}$. The definition of 'consultation' in this respect was ambiguous. There were no clear terms of reference and such decisions tended to be left to the 'better judgement' of the department heads at the BBC and ITA respectively. Consequently, the extent to which CRAC could be seen as truly 'representative' was often

\footnotetext{
${ }^{21}$ Section eight of the Television Act 1954, Chapter 55. London: HMSO.

${ }^{22}$ Report of the Committee on the Future of Broadcasting (1977) London: HMSO, p.322.
} 
Genesis of the Bible documentary: the development of religious broadcasting in the UK. Chapter for Adams, E. \& Bond, H. (Eds), 2019 The Bible on Television (London: Bloomsbury). This document is the author's submitted version. There may be differences between this version and the published version. You are advised to consult the publisher's version if you wish to cite from it.

brought into question ${ }^{23}$. CRAC was thought to be well positioned to advise the new ITA as it did the BBC, on general matters of broadcasting policy, but not to offer advice on practical day-to-day programme planning. Consequently it was decided that in addition to CRAC a small Panel of Religious Advisors should be set up which would meet monthly for the ITV companies.

By the late 1950's, the growing ITV network was flourishing. With the UK transmission of popular American comedy like I Love Lucy (CBS, 1951-57), and crime dramas like Dragnet (NBC, 1951-1959), audiences grew rapidly. Hughie Green's Double Your Money (Associated Rediffusion, 1955-1964) and other quiz and money games were also introduced. From 1957 onwards profits increased to such a degree that Roy Thomson of Scottish Television was prompted to make his famous analogy of an ITV license being like a license to print money. By the end of the decade ITV was watched by more than 70 per cent of the audience who had a choice ${ }^{24}$.

\section{'Authentic' religious programmes}

If the 1950s had been the decade of ITV, the 1960s were to see a renewed sense of confidence on the part of the BBC under Director-General Hugh Greene. The Corporation was granted a second channel in 1964 (BBC2). Greene wanted to lose the Corporation's 'auntie' image, and to reflect something of the spirit of the sixties. New series like $Z$ Cars (BBC, 1962-1978) about tough and cynical police in a working-class northern town, and the satirical That Was The Week That Was (BBC, 1962-1963) were so far removed from what had come to be expected of the BBC that many people took exception. That Was The Week

\footnotetext{
${ }^{23}$ A matter debated by the General Synod of the Church of England, in Broadcasting, Society and the Church (1973) London: CIO, pp.63-64.

${ }^{24}$ A. Davis (1976) Television: The First Forty Years, London: Severn House Publishing, p.18.
} 
Genesis of the Bible documentary: the development of religious broadcasting in the UK. Chapter for Adams, E. \& Bond, H. (Eds), 2019 The Bible on Television (London: Bloomsbury). This document is the author's submitted version. There may be differences between this version and the published version. You are advised to consult the publisher's version if you wish to cite from it.

That Was in particular pushed at the boundaries of what was acceptable for public taste, with almost no area of public life spared from its savage wit, religion included.

During the early days of television, religious broadcasters had experimented with different programme styles and formats. Jesus of Nazareth (BBC, 1956) was an early attempt to use drama $^{25}$ to achieve for religious television what Dorothy L. Sayers' series had achieved for radio. Without the formidable personality of Sayers to drive it forward, the project became ensnared in a tortuous consultative operation, which nearly sunk the project entirely (involving representatives from the Ministry of Education, University departments, as well as clergy). Nevertheless, despite the difficulties, and the inevitable misgivings in advance of the broadcast, the eight-part series was enthusiastically received, and went on to win a BAFTA. Personalities like Malcolm Muggeridge and Donald Soper had also become well known for their appearances in religious discussion programmes and television 'panels'. The straight-to-camera religious talk was now well established in the form of the nightly epilogue, and a variety of different treatments were used in televising church worship. Despite these developments there remained concerns that television was fundamentally ill equipped to deal with religion; that it was an inherently more trivializing medium than radio; and that increasing the quantity of programmes should be a concern secondary to increasing their quality.

By the early 1960s, the full effect of competition was beginning to be felt. There was a concerted effort to make the devotional programme more accessible and entertaining. Songs of Praise (BBC, 1960-ongoing) featured popular hymns sung in churches, but without

\footnotetext{
${ }^{25}$ A major Italian co-production of the same name was aired on ITV some 21 years later: Zefferelli's Jesus of Nazareth (ITV, 1977).
} 
Genesis of the Bible documentary: the development of religious broadcasting in the UK. Chapter for Adams, E. \& Bond, H. (Eds), 2019 The Bible on Television (London: Bloomsbury). This document is the author's submitted version. There may be differences between this version and the published version. You are advised to consult the publisher's version if you wish to cite from it.

the accompanying rituals or sermons (interviews were included in later years). This musicbased formula was pushed still further in the direction of mass audience appeal.

The closest that religious television in the UK has come to a light entertainment format was Stars on Sunday (Yorkshire Television, 1969-79). The show was conceived by Yorkshire Television's Head of Children's Programmes, Jess Yates, noted for the success of his Junior Showtime (Yorkshire Television, 1969-1974). Yates saw the Sunday evening 'closed period' as a perfect opportunity to find a populist show that 'over 65's could call their own' by harnessing it to popular religious sentiment:

Religion comes into it because we felt that the period devoted to religious-type programmes was the only really suitable time for a series of this kind. In any case, the majority of the people for whom we were catering sought warmth, comfort and peace from religion. ${ }^{26}$

The new show was launched as a 13-part series in the Autumn 1969. Yorkshire television's design department provided an ornate country house set (30ft high pillars, ornamental lake, waterfalls, and ever-blooming rose garden) in which celebrities appeared singing popular sacred songs and hymns, or reading passages from the Bible. In addition to these wellknown 'stars', Yates also used the programme as a showcase for up-and-coming talent (similar to the approach he had taken with Junior Showtime). The show had a degree of glitziness previously unknown to religious broadcasting in the UK, which attracted large audiences and repelled critics in equal measure. Reviewing for The Sunday Observer, Clive James described one episode of the show as:

...self-serving sentimental goo, a substance which spreads like a steaming fen in the diabolical Stars on Sunday. Jess Yates was on particularly winning form last week, telling us to ring somebody up - anybody - and thank them, not omitting a quick call to God to thank him too... T.S. Elliot once pointed out, unarguably, that the New English Bible had been compiled by people who didn't even know they were

\footnotetext{
${ }^{26}$ Stars on Sunday. Programme from the Futurist Theatre, Scarborough. 1972. p.3.
} 
Genesis of the Bible documentary: the development of religious broadcasting in the UK. Chapter for Adams, E. \& Bond, H. (Eds), 2019 The Bible on Television (London: Bloomsbury). This document is the author's submitted version. There may be differences between this version and the published version. You are advised to consult the publisher's version if you wish to cite from it.

atheists. The same applies in full measure to Stars on Sunday, in which all the faith is blasphemy and every piety is an insult. ${ }^{27}$

Despite the hostility, within its first year Stars on Sunday attracted over 250,000 letters of gratitude, requests for prayers, hymns, and Bible readings. Within two years it was attracting a regular viewing audience of 15 million, sometimes growing to 17 million, making it the first religious programme to enter the viewing charts. ${ }^{28}$

The tension between adopting a populist approach to reaching a mass audience on the one hand, and producing what would be acceptable religious content on the other - a conflict between medium and message - soon became a significant problem. The show was demonstrably popular, yet the ITA was reprimanding Yorkshire Television for failing to provide authentic religious content within the closed period. Yates turned to the Evangelical cleric, Brandon Jackson ${ }^{29}$ (an ITV Advisor) for scripts that would provide the programme with the religious authenticity being demanded. Jackson took the offer as an evangelistic opportunity, and set about attempting to use the format to blend what he saw as the value of folk religion and popular sentimentality on the one hand, with orthodox theological and Biblical reflection on the other. Throughout, Jackson fiercely defended the programme against its critics within the Church of England, convinced that, through its broad appeal, it could achieve a great deal for religion:

It appealed to those people whom the church fails to touch. It was doing something that the churches were not able to do, not because the churches don't try, but because the church has still not come to terms with modern methods of communication [...] At this time it was doing what I think was an awful lot of good and making the churches, on the whole, very very cross.

\footnotetext{
${ }^{27}$ Clive James, 'O Lord, preserve us', The Sunday Observer, 19th May 1974.

${ }^{28}$ Figures cited in the Scarborough programme.

${ }^{29}$ ITV Advisor, Jackson, was vicar of St. Peter's, Shipley, and later to become Dean of Lincoln Cathedral, where he was caught up in other controversies.
} 
Genesis of the Bible documentary: the development of religious broadcasting in the UK. Chapter for Adams, E. \& Bond, H. (Eds), 2019 The Bible on Television (London: Bloomsbury). This document is the author's submitted version. There may be differences between this version and the published version. You are advised to consult the publisher's version if you wish to cite from it.

Nevertheless, Jackson felt himself to be in a continual state of tension between message and medium:

It was a battle that I never really won. I wanted to make it an authentic Christian religious progamme, but the image or picture is stronger than the spoken word. The image can very often negate the spoken word, and the lavish 'country house'-style and the gorgeous dresses of these girls (often very low cut and looking very sensuous) didn't always comply with the sort of message that one was trying to put across. ${ }^{30}$

The fashioning of Yates into what James had unkindly dubbed 'the Deity's private secretary ${ }^{31}$ was to trigger the demise of Yates' career. Jackson's words, as spoken by Yates, proved to be a toxic mix when revelations about the presenter's private life surfaced in July 1974. Appetite for highly populist formats for religious programmes waned, and it was to the documentary that attention then turned.

\section{The rise of the documentary}

In the same year as Montagnon's epic series The Long Search (BBC, 1977), the BBC also broadcast: Who was Jesus? (BBC, 1977) presented by the Cambridge philosopher, Don Cupitt (at the time, attracting widespread controversy for his contribution to the symposium The Myth of God Incarnate); and a major series called BC: The Archaeology of Bible Lands (BBC, 1977), in which presenter Magnus Magnussen travelled through Palestine and Syria examining the Bible through archaeology, from pre-history to the fall of Jerusalem in $70 \mathrm{AD}$ (courting controversy by what many considered to be a selective and partial account). On ITV, Bamba Gascoigne's The Christians (Granada Television, 1977) was a similarly styled thirteen-part series on the history of Christianity. It was also the year in which the BBC launched their new religious documentary series Everyman (BBC, 1977-

\footnotetext{
${ }^{30}$ Very Rev. Brandon Jackson, Provost of Bradford. Interview with the author, 25th October 1985.

${ }^{31}$ Clive James (1974).
} 
Genesis of the Bible documentary: the development of religious broadcasting in the UK. Chapter for Adams, E. \& Bond, H. (Eds), 2019 The Bible on Television (London: Bloomsbury). This document is the author's submitted version. There may be differences between this version and the published version. You are advised to consult the publisher's version if you wish to cite from it.

2005). These were all programmes about religion, as distinct from religious programmes in the sense that would have been understood by an earlier generation of programme makers. This emergence of the religious-themed documentary must be seen in relation to a new kind of programme-maker that was emerging in television at this time. Wherever there is industrialization or the kind of expansion that broadcasting had undergone since 1954, division of labour and new types of specialism emerge. Occupations that grow out of such specialism are defined and justified in terms of 'an ordered distribution of work which carries with it some moral responsibilities, in return for which [workers] acquire moral legitimation for the part they play in the social drama of work ${ }^{\prime 32}$. In the early days of television, programme makers had inevitably been drawn from elsewhere, often for their specialized knowledge of a particular discipline (religious broadcasting departments being headed by clerics, for example). During the sixties, however, a new generation of programme makers began to emerge whose specialized area of knowledge was of the medium itself. Colin Morris describes them as the Young Turks: a cultural elite, mainly from the middle-classes and molded by public school and Oxbridge:

Having been trained to use film or video, operate in studios or outside broadcast units, many Young Turks can move effortlessly from science to music and arts, from current affairs to sport. Some inevitably stay put in one department and in this sense specialise, but more give a fair impression of being modern Renaissance men and women - immensely versatile in their interests and knowledge. ${ }^{33}$

In his study of the BBC, Tom Burns discusses how widely the term 'professional' was being used during the time of his first study in 1963, and how its use increased over the following decade:

There were times when it seemed that the word was being credited among programme staff with an almost talismanic quality, representing some absolute principle by which to judge people and

\footnotetext{
32 T. Burns (1977) The BBC: Public Institution and Private World, London: Macmillan Press Ltd., p.131.

${ }^{33}$ Colin Morris (1984) God-in-a-Box: Christian Strategy in the Television. London: Hodder and Stoughton.
} 
Genesis of the Bible documentary: the development of religious broadcasting in the UK. Chapter for Adams, E. \& Bond, H. (Eds), 2019 The Bible on Television (London: Bloomsbury). This document is the author's submitted version. There may be differences between this version and the published version. You are advised to consult the publisher's version if you wish to cite from it.

achievement. Ten years later the word seemed to occur even more frequently, to have acquired a wider and more potent range of meanings and connotations, and to be used throughout all reaches of the Corporation. Among senior management in charge of television and radio it had assumed the character of some ultimate rationale... ${ }^{34}$

Burns found that this 'cult of professionalism' had slowly superseded the notion of public service as the principal rationale for evaluating programmes:

...the transition of broadcasting from an occupation dominated by the ethos of public service, in which the central concern is with quality in terms of the public good, and of public betterment, to one dominated by the ethos of professionalism, in which the central concern is with quality of performance in terms of standards of appraisal by fellow professionals; in brief, a shift from treating broadcasting as a means to treating broadcasting as an end. ${ }^{35}$

This change would inevitably have repercussions for religious broadcasting. Whereas in the past, programme makers were presumed to possess an understanding of religion and an empathy with religious practice, this new professionalism was more commonly characterized by scepticism about religion, and distance from religious practice.

The first significant effect of these young professionals upon religious programmes was felt in 1975 with the appointment of Peter Armstrong to replace the Revd. J.G. Day as Head of Religious Programmes at BBC Television. Armstrong was young and he was not a cleric. He disliked what he perceived as being a 'closed period mentality' within religious broadcasting at the time: 'It felt like a piece of propaganda by the Christian lobby; something like a party political broadcast... In other words, the Church would always win the argument. ${ }^{36}$ His aim was to develop a strand of programming that would both physically move out of the traditional 'closed period', and would look at religious issues in

\footnotetext{
34 T. Burns (1977), p.123

35 T. Burns (1977), p.125.

${ }^{36}$ Peter Armstrong. Interview with the author: 11th July 1985.
} 
Genesis of the Bible documentary: the development of religious broadcasting in the UK. Chapter for Adams, E. \& Bond, H. (Eds), 2019 The Bible on Television (London: Bloomsbury). This document is the author's submitted version. There may be differences between this version and the published version. You are advised to consult the publisher's version if you wish to cite from it.

the same way as Horizon (BBC, from 1964) would cover science and philosophy, or Panorama (BBC, from 1953) would examine current affairs:

We wanted to try and find a programme that would quite consciously work from the normal assumptions, and the best assumptions that we thought to take were the Current Affairs ones... And we'd say to the viewer, 'we're going into this question in a completely open-minded way'. It may be that it would come out as an attack on the Church, or support for the Church, or it may be on a secular issue which the Church doesn't think is important and ordinary people do... We tried to create a format that would be clearly honest reporting for the general audience.

This move made room within the department for more Young Turks:

We had young television professionals, not clerics. On the whole the producers of the 1950's and '60's were retrained clergy, whereas I preferred to take young television professionals who were interested in religion and who would learn more about that - if they didn't know it - rather than trying to learn television technique.

Recalling his time as a young researcher in the religious programmes department in the late 1970s, Mark Thompson (later to become Director-General of the BBC) recalled that 'most editions of Everyman were only "religious" in the broadest possible sense': 'Even among religious programme-makers ... there was a real anxiety about whether religion as a thing in itself was a topic of any real interest. And outside the specialist departments, religion was marginal at best. ${ }^{37}$ Thompson suggests that the prevailing background assumptions ('so widespread - both within and beyond the media - as to be normative') were:

...that familiar post-Enlightenment claim that the rationalist arguments against belief in God are so persuasive that they spell the inevitable long-term decline of organised religion. Progress brings education and knowledge, and education and knowledge inexorably undermine belief.

Everyman was launched in the schedules on Sunday at the later time of $10.30 \mathrm{pm}$. The risky

\footnotetext{
${ }^{37}$ Mark Thompson (2008), Faith And The Media: Speech given at Cardinal Cormac Murphy O'Connor Lecture 2008 series. Faith And Life In Britain Today, Westminster, London. Thursday 10 April 2008. Available: http://www.bbc.co.uk/pressoffice/speeches/stories/thompson_faith.shtml. [Accessed: 20 March 2015].
} 
Genesis of the Bible documentary: the development of religious broadcasting in the UK. Chapter for Adams, E. \& Bond, H. (Eds), 2019 The Bible on Television (London: Bloomsbury). This document is the author's submitted version. There may be differences between this version and the published version. You are advised to consult the publisher's version if you wish to cite from it.

decision to break out of what had become 'the God slot' prompted much debate within CRAC as to the wisdom of such a move. For the first five years after restrictions on broadcasting hours had been officially lifted (in 1972), the seventy-minute period of backto-back broadcasting with ITV on a Sunday evening, had remained in place by mutual agreement. Placing a religious programme outside of this period might be an indication of BBC confidence in Everyman, but the consequent reduction of the closed period could end up being more broadly detrimental in the longer term. The Economist predicted:

...there may be some grumbling from the ranks of the more conservative churchmen - and laymen - who may see the halving of the God slot as the thin end of the wedge and the beginning of the end of religion on the air - despite the BBC's assurances. ${ }^{38}$

Robert Runcie, then Bishop of St. Albans and chair of CRAC, however, enthusiastically supported Armstrong's decision. It was Runcie's conviction that religious broadcasting generally should be encouraged to 'stand on its own feet' and compete for viewing time. As a result the decision was taken to reduce the agreed period of back-to-back broadcasting with ITV to thirty-five minutes, and allow the remaining time to float between $4.00 \mathrm{pm}$ and $10.45 \mathrm{pm}$. For the time being, ITV would continue to occupy the full 70 minutes with religious programmes. The Daily Telegraph asserted that 'the claustrophobia of the old closed period has at last gone for good' ${ }^{39}$, but The Guardian suggested that CRAC may have been 'bought off' by 'BBC progressives' ${ }^{\prime 4}$. It was a debate that was to blow up again six years later.

Significantly, the first Everyman programme, Inspiration Incorporated (10 Apr. 1977) was a cautionary tale of US-style unregulated religious broadcasting: a sceptical appraisal of the

\footnotetext{
${ }^{38}$ On its own feet, The Economist, 258, 13 March 1976, p.29.

${ }^{39}$ Peter Knight, Giving more scope to religion, Daily Telegraph, 29 August 1977, p.5.

${ }^{40}$ Baden Hickman, God slot for the chop, The Guardian, 1 March 1976, p.17.
} 
Genesis of the Bible documentary: the development of religious broadcasting in the UK. Chapter for Adams, E. \& Bond, H. (Eds), 2019 The Bible on Television (London: Bloomsbury). This document is the author's submitted version. There may be differences between this version and the published version. You are advised to consult the publisher's version if you wish to cite from it.

work of controversial 'televangelist' Bob Schuyler, noted for his weekly Hour of Power broadcast from his Crystal Cathedral in Orange Grove, California. Everyman was questioning, interrogative, and explicitly not the mouthpiece of religious orthodoxy. The second programme, The Lord's My Shepherd and He Knows I'm Gay (17 Apr. 1977) profiled the recently founded (and at the time, controversial) Gay Christian Movement. Programmes were committed only to the 'normal assumptions of television', and presented by 'religious sceptic' Peter France, in the style of other mainstream documentary strands, indistinguishable but for a focus on religious or moral themes.

Everyman became the longest-running religious documentary series ever produced for UK television, and signified a major shift in approach that was reflected in many shorter-lived series, including Joan Bakewell's Heart of the Matter (BBC, 1987-2000), and Credo (London Weekend Television, 1978-1986). Rev. John Lang, the BBC's overall Head of Religious Broadcasting, described the changes in terms of 'strong plants' that at last could be 'put out into the garden'41, exemplifying a prevailing optimism that religion was 'coming out of the ghetto'.

\section{Changing objectives \& the demise of the 'God slot'}

By the publication of a further Government-commissioned Report on the Future of Broadcasting (The Annan Report) in 1977, the aims of religious broadcasting were felt to be in need of 'revision and reinterpretation'. Annan's report devoted a total of nine pages (Chapter 20), to the subject of religion, beginning with the observation that whilst church attendance had declined, there remained a considerable interest in religion and people were still asking questions about eternity. There had been a proportional decrease in the amount of time devoted to religion and a significant reduction in the time devoted to

\footnotetext{
${ }^{41}$ Daily Telegraph, 29 August 1977, p.5.
} 
Genesis of the Bible documentary: the development of religious broadcasting in the UK. Chapter for Adams, E. \& Bond, H. (Eds), 2019 The Bible on Television (London: Bloomsbury). This document is the author's submitted version. There may be differences between this version and the published version. You are advised to consult the publisher's version if you wish to cite from it.

religion within the traditional 'closed period'. However, the Report observed that 'the best sermons are not necessarily the longest' and no recommendation was made that the time devoted to religion should be increased. The concern of the Committee, it said, was over the quality of those programmes that were produced.

An important aspect of this section of the Report is its discussion of the submission it had received from CRAC, in which the advisory body had reflected on its own position, and offered a revised set of guidelines for the aims of religious broadcasting.

For the Pilkington Report fifteen years earlier, CRAC had defined religious broadcasting as having three objectives:

The first was to reflect the worship, thought and action of those churches which represent the mainstream of the Christian tradition in this country. The second was to stress what was most relevant in the Christian faith for the modern world. The third was to try to reach those outside the churches or only loosely attached to them. ${ }^{42}$

The 'revision and reinterpretation' of these objectives became:

(i)To seek to reflect the worship, thought and action of the principal religious traditions represented in Britain, recognising that those traditions are mainly, though not exclusively, Christian.

(ii)To seek to present to viewers and listeners those beliefs, ideas, issues and experiences in the contemporary world which are evidently related to a religious interpretation or dimension of life.

(iii)To seek also to meet the religious interests, concerns and needs of those on the fringe of, or outside the organised life of the Churches. ${ }^{43}$

Although Annan comments that this was 'less of a change than at first sight appears', in reality it was an important shift on two counts: first, the term 'religion' had broadened from meaning exclusively Christian; second, while broadcasting was to cater for the 'needs' of

\footnotetext{
${ }^{42}$ Annan Report (1977) p.319.

${ }^{43}$ Report (1977) p.319.
} 
Genesis of the Bible documentary: the development of religious broadcasting in the UK. Chapter for Adams, E. \& Bond, H. (Eds), 2019 The Bible on Television (London: Bloomsbury). This document is the author's submitted version. There may be differences between this version and the published version. You are advised to consult the publisher's version if you wish to cite from it.

people outside the churches, it was not to proselytize.

ITV's initial response to Everyman's place in the schedule was to continue with its own religious programmes across the seventy-minute God slot as before. By 1983, however, Credo, the principle occupant of the $6.00 \mathrm{pm}$ slot was losing a considerable percentage of its viewing audience to the BBC's travel and light-entertainment programmes. Consequently, in August 1983, Credo was rescheduled to the Sunday 'graveyard' slot of $2.00 \mathrm{pm}$. This time, the move was strongly resisted. The Times leader column rebuked the Independent Broadcasting Authority (IBA) ${ }^{44}$ for having thrown an important debate - that of the place of religion on television - 'into the brutal cockpit of the ratings battle': 'It is not easy to regard the Authority's decision as having enhanced the quality of British television, or as having properly protected the public interest, which they exist to do ${ }^{\prime 45}$. The article went on to then admonish the BBC retrospectively for its 'aggressively competitive' scheduling against ITV: 'They are both slaves... to the doctrine that ratings are the all-important test of public wants and needs, and that what really matters is to drive the figures upwards at all costs'.

The accusations and justifications ran on, as evidenced in a series of exchanges in The Times. Colin Morris, then Head of Religious Broadcasting for BBC Television pointed out that in the case of Everyman, the move had been to reach a larger, not a smaller audience. John Whitney, Director General of the IBA, justified Credo's move on the basis of it being impossible for a self-financing service to 'overlook the realities of its commercial situation'46. Angus Wright, Head of Religious Programmes for Television South, countered this by pointing to recent figures indicating huge increases in ITV revenue and audience

\footnotetext{
${ }^{44}$ The responsibilities of the ITA were expanded to include commercial radio in the Sound Broadcasting Act of 1972, and the Authority was renamed accordingly.

45 The Times, 18 August 1983, p.9.

${ }^{46}$ The Times, 23 August 1983, p.9.
} 
Genesis of the Bible documentary: the development of religious broadcasting in the UK. Chapter for Adams, E. \& Bond, H. (Eds), 2019 The Bible on Television (London: Bloomsbury). This document is the author's submitted version. There may be differences between this version and the published version. You are advised to consult the publisher's version if you wish to cite from it.

figures, referring to the cheaper studio-based format that Credo had adopted as a 'progressive rundown in resources and production values of the principal occupants of the $6.00 \mathrm{pm}$ Sunday slot' - just another sympton of ITV's 'bad scheduling'47. Paul Neuburg, the Editor of London Weekend Television's Credo refuted this blaming 'the demise of the backto-back arrangement for religious programmes between ITV and $\mathrm{BBC}^{48}$.

The end of the seventy-minute closed period and the ensuing debate both in 1977, and then again in 1983, highlighted a growing unease among many people that religion was being 'pushed out' of the schedule. Despite its earlier support of the BBC, the move of ITV's Credo to the early afternoon was strongly resisted by CRAC. Donald Reeve, a serving member of CRAC for nine years, reflected this tension:

The Mafia of professional religious broadcasters and media bureaucrats have the idea firmly installed in memoranda and in their heads that religion is a minority interest like potholing. That is why the Independent Broadcasting Authority has decided to switch ITV's main religious programmes on Sunday from 6.00 p.m. to 2.00 p.m. The Central Religious Advisory Committee is dismayed. The decision could mark the beginning of the end for religious programmes on television ... ${ }^{49}$

A view that was becoming increasingly discernable within the churches by the 1980's was that religious broadcasting was 'under attack' and CRAC could do little about it.

The most significant outcome of The Annan Report was the proposal it made for what was to become Channel 4. Although the Report's particular vision for the channel was not implemented in full, it nevertheless set in motion a plan for a fourth channel that was to be funded by advertising, have a public service remit, and cater for minority groups and interests. It is important to note just what the prospect of a fourth Channel represented for

\footnotetext{
${ }^{47}$ The Times, 22 August 1983, p.11.

${ }^{48}$ The Times, 30 August 1983, p.11.

${ }^{49}$ The Big Why? The Universe, 19 August 1983, p.6.
} 
Genesis of the Bible documentary: the development of religious broadcasting in the UK. Chapter for Adams, E. \& Bond, H. (Eds), 2019 The Bible on Television (London: Bloomsbury). This document is the author's submitted version. There may be differences between this version and the published version. You are advised to consult the publisher's version if you wish to cite from it.

many within the churches at this moment. As has already been suggested, by the late $1970 \mathrm{~s}$ there was an escalating sense of lost ground. The privilege and protection that religious broadcasting had enjoyed up to and through the war years - initially unappreciated, and subsequently, largely taken for granted - could no longer be presumed. Commercial pressures, as illustrated by the demise of the God slot, new notions of what constituted 'professionalism' (and 'impartiality') seemed to be evidence of a powerful secularising process at work. Religious broadcasting was felt by many to be moribund. These factors, together with the widespread take-up of the VHS, and the possibilities that seemed to be on the horizon with the arrival of cable and satellite broadcasting, all suggested a very uncertain future. There was a consequent growing interest in (as well as widespread alarm about) religious groups accessing airtime more directly, and US-style religious programmes now seemed like a distinct possibility50. The idea of Channel 4 as a publisher-broadcaster, challenging the old duopoly by commissioning content from a broader pool of programmemakers, but with a public service remit to cater for minority groups, seemed to promise much. A number of independent religious groups set about organizing themselves to take programme proposals to the new channel, including the mainstream denominations who collectively initiated the British Churches Committee for Channel Four (BCCC4) ${ }^{51}$.

These great expectations for what the new channel might offer religious broadcasting, against the background of a growing sense of disaffection about the direction of travel of the religious output of both the BBC and ITV, go some way towards explaining the enormous disappointment that was to follow. Channel 4's first Commissioning Editor for Religion was

\footnotetext{
${ }^{50}$ Manchester-based Good News Television, for example, approached US televangelist, Jim Bakker, and produced a UK pilot version of his talk show, The PTL Club, then offered to (but rejected by) Channel 4.

${ }^{51}$ Rt. Rev. Stewart Cross, Bishop of Blackburn, A proposal for the 'British Churches Committee for Channel Four' (London: unpublished, 1982).
} 
Genesis of the Bible documentary: the development of religious broadcasting in the UK. Chapter for Adams, E. \& Bond, H. (Eds), 2019 The Bible on Television (London: Bloomsbury). This document is the author's submitted version. There may be differences between this version and the published version. You are advised to consult the publisher's version if you wish to cite from it.

John Ranelagh, a self-described 'enthusiastic agnostic'52. Ranelagh had no interest in CRAC and the existing advisory structure, believing that professional programme makers would seek out advice appropriate to the needs of their projects. During his first year at the channel he rejected all of the programme ideas that had been submitted to him by the BCCC4 (as well as those from other independent religious groups), and instead, turned to one of the big beasts of ITV, London Weekend Television, for his first major commission. Jesus: The Evidence (London Weekend Television for Channel 4,1984) was a highly tendentious Easter documentary series that set itself up as revealing an explosive debate (illustrated by an exploding image of Jesus) which, it claimed, had been 'simmering quietly for the last two centuries' ${ }^{53}$. The furore that surrounded the series (orchestrated principally by the evangelical magazine, Buzz) represents a high water mark in a rising sense of disentitlement on the part of the churches. It became emblematic of the cultural dissonance that by now was felt to exist between the religious and the broadcasting institutions ${ }^{54}$. It was Clifford Longley, the Religious Affairs Correspondent for The Times, who accurately noted that Channel 4 was 'not so much the last of the main public service channels to arrive, as the first swallow heralding the broadcasting pluralism of cable and satellite' ${ }^{55}$. This was a reality that few in the churches had properly understood.

\section{Conclusion}

This chapter has aimed to provide a context for the Bible documentary by setting its

\footnotetext{
${ }^{52}$ John Ranelagh, interview with author, April 1985.

${ }^{53}$ Julian Norridge, Jesus: The Evidence. What's New at LWT. April 1984, 13, pp.4-5.

${ }^{54}$ For a full account, see Richard Wallis, Channel 4 and the declining influence of organised religion on UK television. The case of Jesus: The Evidence, Historical Journal of Film Radio and TV, Forthcoming.

${ }^{55}$ Clifford Longley, Sceptics discount vital evidence. The Times, 9 April 1984; p. 14.
} 
Genesis of the Bible documentary: the development of religious broadcasting in the UK. Chapter for Adams, E. \& Bond, H. (Eds), 2019 The Bible on Television (London: Bloomsbury). This document is the author's submitted version. There may be differences between this version and the published version. You are advised to consult the publisher's version if you wish to cite from it.

emergence within the broader frame of religious programme making from its earliest days. To help make sense of subsequent trends discussed by others in this volume (including the approaches taken by programme makers, the role of advisors, and the attitude of the churches), it has been important to note several significant changes that occurred over the period discussed here. At its birth, religious broadcasting in the UK was privileged and protected to a degree that, even given the less secularised society of the time, was far from inevitable, and was ultimately unsustainable. The primary objective of religious broadcasting from the beginning was unashamedly evangelistic, and this was positioned as entirely compatible with the BBC's public service remit and educational agenda, based on the justification that, historically, British society was Christian. Accordingly, those involved in religious broadcasting were generally expected to have been theologically trained, and have an understanding of, and empathy with, religious practice - indeed, many were clerics. However, from the war years onwards, this position began to alter. Key features of these changes included: a shifting idea of what the objectives of religious broadcasting ought to be; growing commercial pressure and the need to attract bigger audiences, particularly on television; and the rise of a new generation of programme makers, who crucially, were neither theologically trained (rather, they were television professionals) nor did they have much affinity with, or understanding of, religious practice. A consequent shift away from older notions of what was meant by public service, and the way in which television professionalism came to be defined, made orthodox and exegetical approaches to religious programmes seem anachronistic. Indeed, it came to be accepted that 'impartiality' ought to presume a religious non-commitment on the part of programme makers (a view that would have been anathema to Reith). Throughout this period, television was trying, and struggling, to find sufficiently popular formats and styles that were thought to be commensurate with religious content, particularly when attempting to reach wider audiences (as illustrates by the problematic nature of Stars on Sunday). This tension between medium and message has continued to be a challenge for programme makers, and this is illustrated by a tendency towards the tendentious in factual and documentary 
Genesis of the Bible documentary: the development of religious broadcasting in the UK. Chapter for Adams, E. \& Bond, H. (Eds), 2019 The Bible on Television (London: Bloomsbury). This document is the author's submitted version. There may be differences between this version and the published version. You are advised to consult the publisher's version if you wish to cite from it.

religious programmes (albeit a feature that is by no means unique to religious programmes). By the 1970s, the questioning, interrogating, and sceptical approach to which the documentary genre lent itself, seemed to be better suited to the new generation of programme makers who were also progressively distancing themselves from traditional structures of advice (CRAC and the ITV advisors increasingly considered to be less than impartial, and outdated). Instead, they relied principally on the perennial skills of the television researcher: personal networks of contacts, publishers, and individual academics and experts brought in only on a programme-by-programme basis. Collectively, these changes resulted in an escalating sense of disentitlement on the part of the Christian churches, which had been slow to welcome or appreciate their initial advantages, and were then slow to understand their altering circumstances, generally lacking the initiative, the coordination, or the strategies to be able to engage with changing times.

There is one further observation that should be made as a concluding point. The twentyfirst century has brought with it a realisation that the seemingly inexorable march of Western secularisation has faltered. Over a period that has been characterised by globalisation, migration, and increasingly complex connections between nations and cultures, religion has resurfaced as a major social, political, and cultural force. 'God is Back!'56 and on the whole, has caught traditional media organisations by surprise. Media professionals, in general, have found themselves to be particularly ill-equipped to engage with a religious landscape that has so long been presumed to be on its way to irrelevance (illustrated by the failure of most media organisations to stem the persistent deprioritising of religious expertise, for example ${ }^{57}$ ).

\footnotetext{
${ }^{56}$ The title of a book by Adrian Wooldridge and John Micklethwait, published in 2010.

57 This is a problem highlighted in the Open University's recent report Religion, Security and Global Uncertainties (2015).
} 
Genesis of the Bible documentary: the development of religious broadcasting in the UK. Chapter for Adams, E. \& Bond, H. (Eds), 2019 The Bible on Television (London: Bloomsbury). This document is the author's submitted version. There may be differences between this version and the published version. You are advised to consult the publisher's version if you wish to cite from it.

A review undertaken by the $\mathrm{BBC}$ in 201758 , resulted in the publication of an ambitious plan within the Corporation to address a growing anxiety about what Adam Dinham has described as the 'lamentable quality of conversation about religion just when we need it most'59. The BBC's review pledges to 'raise our game across all output', including: increased specialist expertise with the appointment of a new Religious Affairs Team and Religion Editor in News; new investment in 'landmark' programmes; more diversity; more crossgenre religious commissioning; a concerted attempt to reach a younger audience; and improved religious literacy training for its staff. At the time of writing, it is still too early to know whether or not this development has, indeed, 'reset' the BBC's approach to religious broadcasting. The review states that the Corporation will 'continue to develop Faith Films on TV - outstanding single documentaries that explore issues of faith within all the major religions in the UK'60. That the Bible documentary has a role to play in providing such insight into religious ideas and practices, and helping audiences to make sense of them in public discourse, is self-evidently vital at a moment when religion is touching our lives in previously unimagined ways.

\footnotetext{
${ }^{58}$ BBC (2017) Religion \& Ethics Review. December 2017. Internal report. Available online: http://www.bbc.co.uk/corporate2/insidethebbc/howwework/reports/religion and ethics 2017 [Accessed: 12 May 2018].

${ }^{59}$ Prof. Adam Dinham in EHRC Dialogues for the Equality and Human Rights Commission (EHRC) and the Government Equalities Office. Available: http://www.religiousliteracy.org/ehrc-dialogues [Accessed: 20 March 2015].

${ }^{60} \mathrm{BBC}$ (2017) Religion \& Ethics Review, p.14.
} 